Али Мазлум' ${ }^{1}$, Н. Г. Зиняков ${ }^{2}$, А. С. Першин ${ }^{3}$, И. В. Шевченко ${ }^{4}$, И. Ю. Жуков ${ }^{5}$, Д. Н. Федосеева ${ }^{6}$, Д. В. Шарыпова ${ }^{7}$, А. С. Иголкин ${ }^{8}$, Н. Н. Власова

'Сотрудник референтной лаборатории по АЧС, ФГБУ «ВНИИЗЖ», г. Владимир, Россия, e-mail: ali.mazloum6@gmail.com

${ }^{2}$ Старший научный сотрудник, кандидат биологических наук, ФГБУ «ВНИИЗЖ», г. Владимир, Рocсия, e-mail: zinyakov@arriah.ru

${ }^{3}$ Научный сотрудник, кандидат ветеринарных наук, ФГБУ «ВНИИЗЖ», г. Владимир, Россия, e-mail:pershin_as@arriah.ru

${ }^{4}$ Научный сотрудник, кандидат биологических наук, ФГБУ «ВНиизЖ», г. Владимир, Россия, e-mail: shevchenko@arriah.ru

${ }^{5}$ Ведущий биолог, ФГБУ «ВНИИЗЖ», г. Владимир, Россия, e-mail: zhukov@arriah.ru

${ }^{6}$ Сотрудник референтной лаборатории по АЧС, ФГБУ «ВНИИЗЖ», г. Владимир, Россия, e-mail: fedoseeva@arriah.ru

${ }^{7}$ Сотрудник референтной лаборатории по АЧС, ФГБУ «ВНИИЗЖ», г. Владимир, Россия, e-mail: sharipova@arriah.ru

${ }^{8}$ Заведующий лабораторией, кандидат ветеринарных наук, ФГБУ «ВНИИЗЖ», г. Владимир, Россия, e-mail: igolkin_as@arriah.ru

${ }_{9}^{9}$ Главный научный сотрудник, доктор биологических наук, ФГБУ «ВНИИЗЖ», г. Владимир, Россия, e-mail: vlasova_nn@arriah.ru

\section{PEЗ ЮME}

К настоящему времени функции многих генов и членов мультигенных семейств вируса африканской чумы полностью не изучены. В частности, не установлены гены, непосредственно обусловливающие вирулентность вируса для организма свиньи. Идентификация таких генов сделает возможным создание делетированных мутантных штаммов вируса АЧС, а также разработку и испытание экспериментальных безопасных вакцин на их основе. При изучении основ патогенности и иммуногенности вируса АЧС основным методом является сравнительный анализ биологических свойств вируса и выявление различий в структуре его генома, влияющих на определенные фенотипические признаки. Наиболее интересным и эффективным подходом к решению данной проблемы является анализ изменений структуры генов при адаптации вируса АЧС к репродукции в перевиваемой культуре клеток. Эти факторы обусловили необходимость получения варианта вируса АЧС, адаптированного к росту в перевиваемой культуре клеток. В процессе адаптации изолята
Одинцово 02/14 вируса АЧС к репродукции в культуре клеток CV-1 удалось получить варианты вируса с измененными биологическими свойствами. При заражении свиней адаптированным вариантом вируса 30-го пассажа летальность составила 16,7\%, причем все выжившие животные приобрели устойчивость к повторному заражению гомологичным вирулентным изолятом Arm 07. Следует отметить, что пассирование вируса в непермиссивной культуре клеток до 30 последовательных пассажей не привело к изменению его генотиповой принадлежности, однако в правой вариабельной концевой области генома появилась крупная делеция размером около 3000 п. н., аналогичная таковой в геноме штамма BA71V, адаптированного к росту в перевиваемой культуре клеток Vero.

Ключевые слова: вирус африканской чумы свиней, адаптация, перевиваемая культура клеток CV-1, генотиповая принадлежность, биопроба, полногеномное секвенирование, генетическая структура, биологические свойства.

UDC 619:616.98:579.852.11

ANALYSIS OF CHANGES

IN AFRICAN SWINE FEVER VIRUS GENETIC STRUCTURE AND BIOLOGICAL PROPERTIES

DURING ADAPTATION TO CONTINUOUS CELL CULTURE

\author{
Ali Mazloum', N. G. Zinyakov' ${ }^{2}$ A. S. Pershin ${ }^{3}$, I. V. Shevchenko ${ }^{4}$, I. Yu. Zhukov' ${ }^{5}$ D. N. Fedoseyeva ${ }^{6}$, D. V. Sharypova7 , A. S. Igolkin ${ }^{8}$, N. N. Vlasova9 \\ 'Specialist of the Reference Laboratory for African swine fever, FGBI “ARRIAH", Vladimir, Russia, e-mail: ali.mazloum6@gmail.com \\ ${ }^{2}$ Senior Researcher, Candidate of Science (Biology), FGBI“ARRIAH”, Vladimir, Russia, e-mail: zinyakov@arriah.ru \\ ${ }^{3}$ Researcher, Candidate of Science (Veterinary Medicine), FGBI “ARRIAH”, Vladimir, Russia, e-mail:pershin_as@arriah.ru \\ ${ }^{4}$ Researcher, Candidate of Science (Biology), FGBI “ARRIAH”, Vladimir, Russia, e-mail: shevchenko@arriah.ru \\ 5Leading Biologist, FGBI “ARRIAH", Vladimir, Russia, e-mail:zhukov@arriah.ru \\ ${ }^{6}$ Specialist of the Reference Laboratory for African swine fever, FGBI "ARRIAH”, Vladimir, Russia, e-mail: fedoseeva@arriah.ru \\ 7Specialist of the Reference Laboratory for African swine fever, FGBI “ARRIAH”, Vladimir, Russia, e-mail: sharipova@arriah.ru \\ ${ }^{8}$ Head of Laboratory, Candidate of Science (Veterinary Medicine), FGBI “ARRIAH”, Vladimir, Russia, e-mail: igolkin as@arriah.ru \\ ${ }^{9}$ Chief Researcher, Doctor of Science (Biology) FGBI “ARRIAH”, Vladimir, Russia, e-mail: vlasova_nn@arriah.ru
}

\section{SUMMARY}

Functions of many African swine fever virus genes and multigene family members have not been yet understood. In particular, no virus genes directly associated with pig virulence have been identified. Identification of such genes will enable preparation of deletion mutant ASF virus strains as well as development and testing of pilot safe vaccines based on the said virus strains. Comparative analysis of the virus biological characteristics and detection of differences in its genome structure affecting certain phenotypic features is a main method used for the virus basic pathogenicity and immunogenicity examination. The most interesting and effective approach to addressing this problem is an analysis of changes in the gene structure during ASF virus adaptation to replication in continuous cell culture. The said factors have made continuous cell culture-adapted variant ASF virus preparation necessary. Variant viruses with modified biological features were prepared during adaptation of ASFV 0dintsovo 02/14 isolate to replication in CV-1 cell culture. Lethality level was $16.7 \%$ when pigs were infected with adapted variant virus at $30^{\text {th }}$ passage and survived animals became resistant to reinfection with homologous virulent ASFV Arm07 isolate. It should be noted that the virus passage in non-permissive cell culture up to 30 serial passages did not result in changes in its genotype; however, a large 3,000 bp deletion similar to that one in continuous Vero-cell culture-adapted BA71V strain genome appeared in right terminal variable region of the genome.

Key words: African swine fever virus, adaptation, continuous CV-1 cell culture, genotyping, bioassay, whole genome sequencing, genetic structure, biological properties. 


\section{ВВЕДЕНИЕ}

Африканская чума свиней (АЧС) - вирусная болезнь домашних и диких свиней, характеризующаяся высокой летальностью и контагиозностью и протекающая в сверхострой, острой, подострой, хронической или инаппарантной форме. Как правило, в начале эпизоотии вирус вызывает сверхострую или острую форму течения болезни с высокой степенью патогенности (смертность приближается к 100\%), далее вирулентность циркулирующего вируса постепенно снижается [4-6].

Так, в Португалии в 1960 г. зарегистрировали вспышку, обусловленную распространением высоковирулентного вируса АЧС, вызывающего 100\%-ю гибель зараженных животных, а через 8 лет циркуляции вируса обнаружили низковирулентный изолят, введение которого обеспечивало у животных выработку иммунитета к последующему заражению исходным изолятом [12].

Распространение АЧС наносит огромные экономические потери, которые складываются из прямых и косвенных затрат на проведение ветеринарно-санитарных и карантинных мероприятий, убоя всего поголовья в очаге, первой угрожаемой зоне и ограничений в международной торговле $[4,8]$.

Очевидно, что для своевременного купирования и ликвидации вспышки АЧС необходимо скорейшее выявление заболевших животных, когда ранняя диагностика дает наилучший эффект в деле защиты здоровья животных и представляет собой крайне сложную составляющую любой эффективно действующей системы надзора за болезнью.

Одним из основных этапов предотвращения распространения заболевания является разрыв эпизоотической цепи, а именно купирование путей передачи возбудителя и элиминация факторов распространения. С этой целью при выполнении надзорных мероприятий по профилактике АЧС и борьбе с ней устанавливаются пути и факторы распространения возбудителя.

Уникальные свойства вируса в сочетании с отсутствием средств специфической профилактики и лечения болезни превращают АЧС в глобальную угрозу свиноводству в нашей стране и за рубежом. Вот почему разработка и совершенствование эффективных мер борьбы с АЧС требуют дальнейшего многостороннего изучения болезни и ее возбудителя.

Вирус АЧС - единственный ДНК-содержащий арбовирус. Размер его генома варьирует от 170 до 193 т. п. н. и содержит от 150 до 167 открытых рамок считывания (ОРС), в зависимости от изолята. ОРС близко расположены друг к другу, имеют перекрывающиеся области и считываются с обеих цепей ДНК $[10,11]$.

Функции многих генов и членов мультигенных семейств вируса АЧС к настоящему времени полностью не изучены. В частности, не установлены гены, непосредственно обусловливающие вирулентность вируса для организма свиньи. Идентификация таких генов сделает возможным создание делетированных мутантных штаммов вируса АЧС, а также разработку и испытание экспериментальных безопасных вакцин на их основе $[6,10]$.

При изучении основ патогенности и иммуногенности вируса АЧС основным методом является сравнительный анализ биологических свойств вируса и выявление различий в структуре его генома, влияющих на определенные фенотипические признаки.

Наиболее интересным и эффективным подходом к решению данной проблемы является анализ из- менений структуры генов при адаптации вируса АЧС к репродукции в перевиваемой культуре клеток, что позволяет выяснить основы патогенности изучаемых вариантов вируса.

Эти факторы обусловили необходимость получения варианта вируса АЧС, адаптированного к росту в перевиваемой культуре клеток. Целью работы был анализ изменений, происходящих в процессе адаптации изолята Одинцово 02/14 вируса АЧС.

\section{МАТЕРИАЛЫ И МЕТОДЫ}

Образцы проб, содержащие вирус АЧС, были получены сотрудниками ФГБУ «ВНИИЗЖ» при проведении адаптации вируса на культуре клеток CV-1.

Первичную и перевиваемую культуру клеток CV-1 выращивали в питательной среде Игла с добавлением 10\% бычьей фетальной сыворотки.

Для изучения биологических свойств адаптированного варианта вируса, определения его способности вызывать заболевание и исследования возможных изменений характеристик возбудителя проводили постановку биопробы посредством заражения поросят изучаемым материалом согласно «Методическим рекомендациям по постановке биопробы с заражением свиней вирусом африканской чумы свиней» (ФГБУ «ВНИИЗЖ»).

Одновременно выполняли оценку уровня контагиозности изучаемых образцов вируса. Для этого использовали незараженных поросят, содержавшихся совместно с зараженными и больными животными.

Наблюдение за животными осуществляли ежедневно, проводя визуальный контроль клинических признаков и ректально измеряя температуру тела каждого подсвинка, в соответствии с «Методическими рекомендациями по оценке клинических признаков и патологоанатомических изменений при экспериментальном заражении вирусом африканской чумы свиней» (ФГБУ «ВНИИЗЖ»). С периодичностью через 2 дня на 3-й у всех животных отбирали пробы крови, а также назальные и ректальные мазки для установления генерализации инфекции с выделением вируса.

Для выявления наличия вируса АЧС в испытуемых образцах и уровня виремии использовали реакцию гемадсорбции в культуре клеток костного мозга свиней (КМС), ПЦР-анализ и реакцию прямой иммунофлуоресценции согласно «Методическим рекомендациям по получению типоспецифической сыворотки крови свиней к вирусу африканской чумы свиней для постановки реакции задержки гемадсорбции», «Методи ческим рекомендациям по выявлению генома вируса африканской чумы свиней методом полимеразной цепной реакции в режиме реального времени» и «Методическим указаниям по выявлению вируса африканской чумы свиней в пробах крови и патологических материалов, отобранных от павших или вынужденно убитых свиней, в реакции прямой иммунофлюоресценции (РПИФ)» (ФГБУ «ВНИИЗЖ»).

Для постановки ПЦР использовали «Тест-систему для диагностики африканской чумы свиней методом полимеразной цепной реакции с гибридизационнофлуоресцентной детекцией в режиме реального времени» (ФГБУ «ВНИИЗЖ»).

Для анализа изменчивости генома в процессе адаптации провели полногеномное секвенирование при использовании реагентов Nextera XT DNA Library Prep 
Kit на платформе секвенатора Illumina MiSeq (Illumina, USA).

\section{РЕЗУЛЬТАТЫ И ОБСУЖДЕНИЕ}

Для оценки возможности выявления изменений биологических свойств и аттенуации вируса АЧС необходимо было провести адаптацию к росту в перевиваемой культуре клеток CV-1 и определить биологические и молекулярно-генетические характеристики данного вируса.

Адаптачия. Первичный вируссодержащий материал изолята Одинцово 02/14 был накоплен в культуре клеток КМС с титром 7,21 $\pm 0,36 \mathrm{lg}\left\lceil\mathrm{Aд}_{50} / \mathrm{CM}^{3}\right.$. Полученный вируссодержащий материал в соотношении 1:10 (v/v) был инокулирован в культуру клеток CV-1, в которой впоследствии было проведено 30 последовательных пассажей аналогичным способом. Причем следует отметить, что эффективная репродукция вируса АЧС в культуре клеток CV-1 регистрировалась только начиная с 12-го пассажа. Результаты экспериментов приведены в таблице 1.

В процессе пассирования в культуре клеток CV-1 к 20-му пассажу (табл. 1) титр вируса достигал $6,21 \pm 0,17 \mathrm{lg}\left\lceil\mathrm{Aд}_{50} / \mathrm{cm}^{3}\right.$, а срок накопления сократился с 14 до 7-8 сут.

При оценке изменений характера гемадсорбции отмечалось уменьшение количества прикрепленных к зараженной клетке эритроцитов (с 40-50 до 30-40) у адаптированного вируса 15-20-го пассажа, а к 30-му пассажу этот показатель снизился до 20-30.

Биопроба. При исследовании инфекционной активности полученного штамма АЧС/BНИИЗЖ/CV-1 вируса АЧС было проведено заражение 6 поросят вируссодержащей суспензией внутримышечно в дозе 10 ГАдЕ/гол., еще 2 подсвинка содержались совместно с инфицированными поросятами для контактного заражения. В результате внутримышечного и контактного методов заражения с выраженными клиническими признаками пали 3 из 8 подопытных поросят, т. е. общая летальность для штамма АЧС/ВНИИЗЖ/CV-1 составила 37,5\%.

При проведении исследований выявили снижение вирулентности и способности штамма АЧС/ВНИИЗЖ/CV-1 индуцировать постинфекционные вирусспецифические антитела, выявляемые с помощью коммерческого диагностического набора ИФА в сыворотке крови до разведения 1:2000 в период до 14 сут после заражения.

Для образца адаптированного к культуре клеток CV-1 вируса 30-го пассажа также провели биопробу на поросятах с использованием дозы 10 ГАдЕ/гол., при этом подопытных животных разделили на 3 группы: 2 поросенка - контактные животные (1-я группа), 2 поросенка - ослабленные бактериальной инфекцией животные (2-я группа) и 4 поросенка - здоровые животные (3-я группа). У всех животных ежедневно измеряли температуру тела. Результаты термографии представлены на рисунке.

Как видно из результатов, представленных на рисунке, температура у поросят контрольной группы не поднималась выше $40,5^{\circ} \mathrm{C}$ за весь срок наблюдения (28 сут), что говорит об отсутствии контактной передачи им вируса.

У ослабленных бактериальной инфекцией животных отмечалась повышенная температура начиная с 5-х сут на 11-е сут 1 поросенок погиб. При его вскрытии были
Таблица 1

Репродукция вируса АЧС (изолят Одинцово 02/14) при адаптации к росту в культуре клеток CV-I $(n=5)$

\begin{tabular}{c|c|c|}
\hline Номер пассажа & $\begin{array}{c}\text { Титр вируса } \\
\left(\lg \left\lceil\text { } Г \mathrm{E}_{50} / \mathrm{cm}^{3}\right)\right.\end{array}$ & $\begin{array}{r}\text { Время накопления } \\
\text { (количество суток) }\end{array}$ \\
\hline 1 & $5,12 \pm 0,25$ & 14 \\
\hline 5 & $4,65 \pm 0,32$ & 12 \\
\hline 10 & $5,46 \pm 0,21$ & $9-10$ \\
\hline 15 & $6,09 \pm 0,24$ & $8-9$ \\
\hline 20 & $6,21 \pm 0,17$ & $7-8$ \\
\hline 25 & $7,08 \pm 0,19$ & 7 \\
\hline 30 & $7,31 \pm 0,12$ & 7 \\
\hline
\end{tabular}

обнаружены поражения, характерные для АЧС, - гиперемия и гипертрофия лимфатических узлов, спленомегалия, воспалительные поражения легких.

У животных 3-й группы отмечался кратковременный подъем температуры до $41-41,3{ }^{\circ} \mathrm{C}$ на 7-9-е сутки. Все животные этой группы оставались живы до окончания срока наблюдения (табл. 2).

Таким образом, в данном опыте летальность для животных 2-й и 3-й групп составила 16,7\%, выраженное изменение биологических свойств адаптированного варианта вируса АЧС 30-го пассажа (снижение летальности с 85,7 до 16,7\%) указывает на наличие вероятных изменений, произошедших в его геноме.

Контрольное заражение. При постановке биопробы с заражением свиней адаптированным вариантом 30-го пассажа вируса АЧС выжили 5 из 6 зараженных животных (группы 2-3) и 2 контактных (группа 1). Для изучения иммунного статуса и определения наличия устойчивости животных к вирусу АЧС провели контрольное заражение. Свиньям внутримышечно ввели вирус АЧС референтного изолята Arm 07 в дозе 1000 ГАдЕ/гол. Выжившие контактные животные 1-й группы были использованы в качестве контроля.

\section{Рис. Термография зараженных животных \\ 1.1 и 1.2 (к) - животные 1-й группы; \\ 2.1 и 2.2 (о) -животные 2-й группы; \\ 3.1, 3.2, 3.3 и 3.4 - животные 3-й группы.}




Таблица 2

Показатели температуры у подопытных животных на 5-14-е сутки после заражения вирусом АЧС 30-го пассажа, адаптированного к культуре клеток CV-1

\begin{tabular}{|c|c|c|c|c|c|c|c|c|c|}
\hline \multirow{2}{*}{$\begin{array}{l}\text { Номер } \\
\text { группы }\end{array}$} & \multirow{2}{*}{$\begin{array}{c}\text { Номер } \\
\text { животного }\end{array}$} & \multicolumn{8}{|c|}{ Сутки после заражения } \\
\hline & & 5 & 7 & 8 & 9 & 10 & 11 & 12 & 14 \\
\hline \multirow{2}{*}{1} & 1.1 (к) & 39,4 & 38,8 & 38,9 & 39,2 & 38,7 & 38,8 & 38,6 & 39,0 \\
\hline & $1.2(\kappa)$ & 39,2 & 39,4 & 39,3 & 39,1 & 39,1 & 39,4 & 39,2 & 39,1 \\
\hline \multirow{2}{*}{2} & $2.1(0)$ & 40,5 & 40,5 & 41,2 & 40,5 & 40,3 & 40,2 & 40,2 & 40,6 \\
\hline & $2.2(0)$ & 40,3 & 41,7 & 41,8 & 41,6 & 41,6 & $\dagger$ & $\dagger$ & $t$ \\
\hline \multirow{4}{*}{3} & 3.1 & 39,4 & 40,0 & 41,3 & 39,6 & 39,6 & 39,8 & 39,3 & 39,0 \\
\hline & 3.2 & 39,9 & 40,1 & 41,0 & 39,1 & 39,0 & 39,7 & 39,5 & 38,8 \\
\hline & 3.3 & 39,9 & 40,3 & 41,3 & 40,1 & 39,0 & 39,6 & 39,5 & 38,8 \\
\hline & 3.4 & 39,5 & 40,3 & 41,1 & 40,4 & 40,1 & 40,2 & 40,3 & 39,6 \\
\hline
\end{tabular}

† - гибель животного.

Температуру всех подопытных поросят замеряли ежедневно в течение всего срока наблюдения (30 сут со дня контрольного заражения).

На 6-7-е сутки контрольные поросята пали с признаками, характерными для АЧС. После контрольного заражения в указанный период у 4 из 5 поросят, выживших после первого заражения, наблюдали вялотекущий конъюнктивит, а температура тела оставалась в пределах физиологической нормы; у 5-го поросенка (из группы ослабленных животных) отмечалось опухание суставов и появление в этой области кровянистых выделений и кожно-некротических образований, характерных для хронического течения АЧС.

Поскольку все животные после контрольного заражения остались живы, а повторных подъемов температуры и появления других клинических признаков АЧС не отмечали, очевидно, что у них выработался протективный иммунный ответ.

Геномный анализ. На основании ПЦР-анализа участка гена B646L, кодирующего основной капсидный белок р72, адаптированный вариант вируса АЧС 30-го пассажа был отнесен к II генотипу. Следовательно, изменения, происходящие при адаптации вируса к росту в непермиссивной культуре клеток, не затронули область, определяющую его классификационные характеристики.

Для определения возможных причин снижения вирулентности адаптированного вируса и сравнительного анализа нуклеотидной последовательности провели полногеномное секвенирование вирусной ДНК, выделенной из клеток CV-1 в соответствии с руководством [1].

В ходе сравнительного анализа полногеномной последовательности адаптированного варианта вируса АЧС (штамм АЧС/ВНИИЗЖ/CV-1 30-го пассажа) и изолята Georgia 2007/1 установлено наличие точечных мутаций в 4 генах (M1249L, NP419L, E199L и I196L). Их функция, по данным L. K. Dixon и соавт., определена в следующем порядке: NP419L - ДНК-лигаза, участвует в репликации вируса; M1249L - участвует в репликации вируса, точная функция не известна; E199L - структурный белок, являющийся трансмембранным доменом белка J-18L, и I196L - функция не известна [3].

Кроме того, как установлено ранее, для адаптированного штамма BA71V наблюдается появление крупной делеции, затрагивающей ген, кодирующий p22 и гены мультигенных семейств MGF100 и MGF360 В правой вариабельной концевой области генома [9]. Анализ геномной последовательности штамма АЧС/ВНИИЗЖ/CV-1 также выявил в области 180 975183920 крупную делецию, составляющую 2945 п. н., что привело к потере генов L7I, L8L, L9L, L10L, L11L и MGF360-18R.

По данным L. K. Dixon и соавт., L10L относится к семейству генов p22, функции L7I, L8L, L9L и L11L еще до сих пор не определены, а ген MGF360-18R относится к семейству MGF360, ответственных за вирулентность вируса АЧС [3].

Следовательно, можно предположить, что существует взаимосвязь между изменениями правой вариабельной концевой области генома, затрагивающей гены L7L, L8L, L9L, L10L, L11L и MGF360-18R, и биологическими свойствами вируса. Это подтверждается экспериментальными исследованиями на животных и коррелирует с результатами, полученными другими исследователями в Испании, Великобритании и США $[2,3,7,9]$.

\section{ЗАКЛЮЧЕНИЕ}

В результате проведенных исследований получен и депонирован в коллекцию штаммов микроорганиз мов ФГБУ «ВНИИЗЖ» адаптированный к росту в перевиваемой культуре клеток CV-I штамм вируса АЧС (АЧС/ВНИИЗЖ/CV-1) 20-го пассажа. Штамм охарактеризован по основным биологическим свойствам, определена возможность его использования для дальнейшей адаптации, а также подана заявка на патент.

В процессе адаптации изолята Одинцово 02/14 вируса AЧС к репродукции в культуре клеток CV-1 удалось получить варианты вируса с измененными биологическими свойствами. Поскольку в ходе постановки био- 
пробы с вариантом вируса 30-го пассажа контактные поросята оставались интактными и неиммунными, можно предположить, что данный вариант вируса утратил контагиозность, характерную для исходного изолята Одинцово 02/14 [6].

При заражении свиней адаптированным вариантом вируса 30-го пассажа летальность составила 16,7\%, причем все выжившие животные приобрели устойчивость кповторному заражению вирулентным изолятом Arm 07.

Следует отметить, что пассирование вируса в непермиссивной культуре клеток до 30 последовательных пассажей не привело к изменению его генотиповой принадлежности, однако в правой вариабельной концевой области генома появилась крупная делеция размером около 3000 п. н., аналогичная таковой в геноме штамма BA71V, адаптированного к росту в перевиваемой культуре клеток Vero.

\section{СПИСОК ЛИТЕРАТУРЫ}

1. Глик Б., Пастернак Дж. Молекулярная биотехнология. Принципы и применение: пер. с англ. - М.: Мир, 2002. - 589 с.

2. African swine fever virus Georgia isolate harboring deletions of MGF360 and MGF505 genes is attenuated an swine and confers protection against challenge with virulent parental virus / V. O'Donnell, L. G. Holinka, D. P. Gladue [et al.] // J. Virol. 2015. - Vol. 89 (11). - P. 6048-6056; DOI: 10.1128/JVI.00554-15.

3. African swine fever virus replication and genomics / L. K. Dixon, D. A. Chapman, C. L. Nethertona, C. Upton //Virus Res. 2013. - Vol. 173 (1). - P. 3-14; DOI: 10.1016/j.virusres.2012.10.020

4. African swine fever // Manual of Diagnostic Tests and Vaccines for Terrestrial Animals / OIE. - $7^{\text {th }}$ ed. - Paris, 2012. - Vol. 2 , Chap. 2.8.1. - P. 1067-1081.

5. African swine fever. Technical Disease Card / OIE. - URL: http://www.oie.int/fileadmin/Home/eng/Animal_Health_in the_World/docs/pdf/Disease_cards/AFRICAN_SWINE_FEVER.pdf (дата обращения: 18.09.18).

6. Biological properties of African swine fever virus Odintsovo 02/14 isolate and its genome analysis / A. A. Elsukova I. V. Shevchenko, A. A. Varentsova [et al.] // Int. J. Environ. Agric. Res. - 2017. - Vol. 3 (10). - P. 26-37.

7. Deletion of African swine fever virus interferon inhibitors from the genome of a virulent isolate reduces virulence in domestic pigs and induces a protective response / A. L. Reis, C. C. Abrams, L. C. Goatley [et al.] // Vaccine. - 2016. - Vol. 34 (39). P. 4698-4705; DOI: 10.1016/j.vaccine.2016.08.011.

8. Detection of African swine fever antibodies in experimental and field samples from the Russian Federation: Implications for control / L. Mur, A. Igolkin, A. Varentsova [et al.] //Transbound. Emerg. Dis. - 2016. - Vol. 63 (5). - P. 436-440; DOI: 10.1111/tbed.12304.

9. Genome sequence of African swine fever virus BA71, the virulent parental strain of the nonpathogenic and tissue-culture adapted BA71V / J. M. Rodríguez, L. T. Moreno, A. Alejo [et al.] // PLoS ONE. - 2015. - Vol. 10 (11):e0142889; DOI: 10.1371/journal. pone.0142889.

10. Genomic analysis of highly virulent Georgia 2007/1 isolate of African swine fever virus / D. A. Chapman, A. C. Darby, M. Da Silva [et al.] // Emerg. Infect. Dis. - 2011. - Vol. 17 (4). P. 599-605; DOI: 10.3201/eid1704.101283.
11. Genotyping field strains of African swine fever virus by partial p72 gene characterization / A. D. Bastos, M. L. Penrith, C. Crucière [et al.] // Arch. Virol. - 2003. - Vol. 148 (4). - P. 693-706; DOI: 10.1007/s00705-002-0946-8.

12. Related strains of African swine fever virus with different virulence: genome comparison and analysis / R. Portugal, J. Coelho, D. Höper [et al.] // J. Gen. Virol. - 2015. - Vol. 96 (Pt 2). - P. 408-419; DOI: 10.1099/vir.0.070508-0.

\section{REFERENCES}

1. Glick B. R., Pasternak J. J. Molecular Biology. Principles and Application: translated from English. - M.: Mir, 2002 (in Russian).

2. African swine fever virus Georgia isolate harboring deletions of MGF360 and MGF505 genes is attenuated an swine and confers protection against challenge with virulent parental virus. V. O'Donnell, L. G. Holinka, D. P. Gladue [et al.]. J. Virol. 2015; 89 (11): 6048-6056; DOI: 10.1128/JVI.00554-15.

3. African swine fever virus replication and genomics. L. K. Dixon, D. A. Chapman, C. L. Nethertona, C. Upton. Virus Res. 2013; 173 (1): 3-14; DOI: 10.1016/j.virusres.2012.10.020.

4. African swine fever. Manual of Diagnostic Tests and Vaccines for Terrestrial Animals. OIE. $7^{\text {th }}$ ed. Paris, 2012; 2, Chap. 2.8.1: 1067-1081.

5. African swine fever. Technical Disease Card. OIE. URL: http://www.oie.int/fileadmin/Home/eng/Animal_Health_in_the_ World/docs/pdf/Disease_cards/AFRICAN_SWINE_FEVER.pdf (access date: 18.09.18).

6. Biological properties of African swine fever virus Odintsovo 02/14 isolate and its genome analysis. A. A. Elsukova, I. V. Shevchenko, A. A. Varentsova [et al.]. Int. J. Environ. Agric. Res. 2017; 3 (10): 26-37.

7. Deletion of African swine fever virus interferon inhibitors from the genome of a virulent isolate reduces virulence in domestic pigs and induces a protective response. A. L. Reis, C. C. Abrams, L. C. Goatley [et al.]. Vaccine. 2016; 34 (39): 4698-4705; DOI: 10.1016/j.vaccine.2016.08.011.

8. Detection of African swine fever antibodies in experimental and field samples from the Russian Federation: Implications for control. L. Mur, A. Igolkin, A. Varentsova [et al.]. Transbound. Emerg. Dis. 2016; 63 (5): 436-440; DOI: 10.1111/tbed.12304.

9. Genome sequence of African swine fever virus BA71, the virulent parental strain of the nonpathogenic and tissue-culture adapted BA71V . J. M. Rodríguez, L. T. Moreno, A. Alejo [et al.]. PLoS ONE. 2015; 10 (11):e0142889; DOI: 10.1371/journal.pone.0142889.

10. Genomic analysis of highly virulent Georgia 2007/1 isolate of African swine fever virus. D. A. Chapman, A. C. Darby, M. Da Silva [et al.]. Emerg. Infect. Dis. 2011; 17 (4): 599-605; DOI: 10.3201/ eid1704.101283.

11. Genotyping field strains of African swine fever virus by partial p72 gene characterization. A. D. Bastos, M. L. Penrith, C. Crucière [et al.]. Arch. Virol. 2003; 148 (4): 693-706; DOI: 10.1007/ s00705-002-0946-8

12. Related strains of African swine fever virus with different virulence: genome comparison and analysis. R. Portugal, J. Coelho, D. Höper [et al.]. J. Gen. Virol. 2015; 96 (Pt 2): 408-419; DOI: 10.1099/vir.0.070508-0. 